\title{
PERANAN ULAMA DALAM MEMBINA MASYARAKAT BANJAR DI KALIMANTAN SELATAN
}

\author{
Ahdi Makmur \\ Fakultas Tarbiyah IAIN Antasari Banjarmasin \\ Jl. A. Yani KM. 4, 5 Banjarmasin, Kalimantan Selatan, 70234 \\ e-mail: ahdimakmur_iain@yahoo.com
}

\begin{abstract}
Abstrak: Tujuan penelitian ini adalah untuk mengetahui peranan ulama dalam pembinaan masyarakat Banjar di Kalimantan Selatan. Peneliti menyimpulkan bahwa ulama memainkan peranan tradisional, meskipun mereka hidup di era Modern. Tanpa memandang tipologinya, ulama telah membawa masyarakat Banjar dalam kesatuan. Ulama memainkan peran besar dalam membina keseimbangan, keharmonisan dan ketunggal-ikaan dari berbagai pandangan, kepentingan dan kelompok masyarakat Banjar. Penelitian juga menemukan bahwa faktor demografi dan sosial budaya tidak memiliki kaitan erat dengan peranan ulama, kecuali faktor religiositas. Dalam masyarakat Banjar, ulama menempati kedudukan yang tinggi karena keilmuan, keterpujian akhlak, kesalehan dan peranan konkret yang mereka lakukan dalam membina masyarakat. Lebih dari itu, karena religiositasnya, pendapat ulama terhadap perubahan sosial, modernisasi, dan pembangunan di Kalimantan Selatan direspons secara positif oleh masyarakat.
\end{abstract}

\begin{abstract}
The Role of Ulama in Developing Banjarese Society of South Kalimantan. This research aims at comprehending the role of ulama in developing Banjar society of South Kalimantan. The author concludes that ulama plays traditional role, provided that they live in modern era. Without considering the typology, ulama has brought the Banjarese society into unity. They have also taken important role in keeping up stability, harmony and diversity from various perspectives, interest, and social groups of Banjarese. It is also revealed that demographic and socio-cultural factors are not closely related with the role of ulama, except that of religiosity. In Banjarese society, ulama is regarded as having high esteem position, due to their knowledge, good character, piety, and their concrete role in social development. In addition, due to their religiosity, their opinions on such fields as social transformation, modernization and development in South Kalimantan are positively responded.
\end{abstract}

Kata Kunci: ulama, masyarakat Banjar, Kalimantan Selatan 


\section{Pendahuluan}

Empat belas abad yang lalu, Nabi Muhammad SAW. adalah pemegang otoritas tunggal urusan agama. Ia menyebarkan, mengajarkan dan mengawal ajaran Islam. Setelah wafat di Madinah $623 \mathrm{M}$, tugas dan tanggung jawab tersebut diteruskan para sahabat, pengikut dan para ulama. Karenaitu, ulama bertugas dan bertanggung jawab menyampaikan (pendakwah), mengajarkan (pendidik) dan memelihara ajaran Islam (pengawal).

Ulama adalah pewaris para nabi (al-'ulamâ' waratsat al-anbiyâ'). Warisan dimaksud adalah ilmu dan kepribadian Nabi Muhammad SAW. Warisan yang tidak ternilai ini mesti dijaga, dipelihara, disebarkan, diajarkan, diamalkan dan dikembangkan untuk kepentingan dan kemaslahatan umat manusia. Dengan demikian, tugas pokok ulama adalah berdakwah dan mendidik. Jika ada ulama yang menjadi politisi dan pengurus organisasi sosial keagamaan, kegiatan berdakwah dan mendidik tidak harus mereka tinggalkan.

Pada abad ke-18, terdapat seorang ulama besar dan termasyhur di Nusantara, yaitu Syaikh Muhammad Arsyad al-Banjari (1710-1812) asal Dalam Pagar Martapura, Kalimantan Selatan. ${ }^{1}$ Ia telah berperanan besar dalam bidang keagamaan, pendidikan, ekonomi dan politik. ${ }^{2}$ Pada abad ke-19, peranan ulama Banjar kurang menonjol, kecuali di lingkungan kerajaan dan dalam perlawanan terhadap penguasa Kolonial. Pada abad ke-20, para ulama kembali memainkan peranan yang signifikan di masyarakat, terutama di bidang pendidikan, dakwah dan politik.

Diangkatnya seorang menteri (menteri muda) penghubung alim ulama di masa kekuasaan Orde Lama ${ }^{3}$ dan dibentuknya wadah alim ulama (MUI) di masa Orde Baru ${ }^{4}$ mengindikasikan pentingnya peranan ulama bagi masyarakat dan pemerintah Indonesia. Tetapi, lembaga yang pertama dihapus, sedangkan yang kedua menjadi mediator atau bahkan cenderung menjadi alat pemerintah.

${ }^{1}$ Profil Syaikh Muhammad Arsyad al-Banjari dapat dibaca dalam buku Hj. Wan Mohd. Shaghir Abdullah, Wawasan Pemikiran Islam Ulama Asia Tenggara, Jilid VI (Kuala Lumpur: Persatuan Pengkajian Khazanah Klasik Nusantara dan Khazanah Fathaniyah, 2004), h. 15-20. Sedangkan biografi beliau yang cukup lengkap telah ditulis dalam buku Abu Daudi, Maulana Syekh Muhammad Arsyad al-Banjari (Martapura: Yapeda, 2003).

${ }^{2}$ Lihat Karel A. Steenbrink, Beberapa Aspek tentang Islam di Indonesia Abad ke-19 (Jakarta: Bulan Bintang, 1984); Siti Zalikhah Md Nor, "Sumbangan dan Pengaruh Syaykh Muhammad Arsyad al-Banjary dalam Bidang Fikih di Alam Malayu," paper presented in International Seminar on the Thought of Syekh Muhammad Arsyad al-Banjari, Banjarmasin, 4-5 Oktober 2003; dan Humaidy, "Pembaharuan Pendidikan Islam Abad XVIII di Kalimantan Selatan," dalam Masdari dan Zulfa Jamalie (ed.) Khazanah Intelektual Islam Ulama Banjar (Banjarmasin: Pusat Pengkajian Islam Kalimantan, 2003), h. 123-152.

${ }^{3}$ Salah seorang Menteri Penghubung Alim Ulama di masa Orde Lama adalah K.H. Fatah Yasin. Lihat Deliar Noer, Partai Islam di Pentas Nasional 1945-1965 (Jakarta: Grafitipers, 1987), h. 398-399.

${ }^{4}$ Majelis Ulama Indonesia (MUI) dibentuk pada tahun 1972 oleh Presiden Soeharto. Ketuanya adalah Prof. Dr. H. Abdul Karim Amrullah (Hamka). Lihat Hamka, "Peranan Ulama Sepanjang Sejarah," dalam Mimbar Ulama, No. 1 (Mei 1976), h. 14-24. 
Peralihan masa Orde Baru (1966-1998) yang otoriter ke era Reformasi yang demokratis memungkinkan terjadinya penguatan peranan ulama dalam masyarakat. Aktivitas ulama tidak lagi dibatasi dan diawasi, sebaliknya mereka diberikan peluang mengambil bagian dalam berbagai aktivitas di masyarakat. Persoalannya ialah apakah momentum yang baik ini dimanfaatkan oleh ulama untuk melakukan peranan mereka secara maksimal, termasuk juga oleh ulama.

Beberapa tulisan tentang ulama Banjar, umumnya dalam bentuk biografi sebagaimana digambarkan oleh Daudi, ${ }^{5}$ Rosyadi, ${ }^{6}$ Karim dan Makmur. ${ }^{7}$ Karena itu, prihal tipologi, peranan dan kedudukan ulama dalam masyarakat Banjar masih perlu dikaji secara khusus dan mendalam. Tulisan ini memfokuskan kajian pada peranan ulama dalam membina masyarakat Banjar di Kalimantan Selatan.

\section{Hakikat Ulama}

Kata ulama adalah bentuk jamak dari kata 'âlim (bahasa Arab), yang berarti seseorang yang memiliki ilmu. Ulama berarti orang-orang yang berilmu. ${ }^{8}$ Di dunia Melayu, digunakan kata-kata (bukan Bahasa Arab) sepertiguru, tok guru dan tuan guru. ${ }^{9}$ Sebutan ulama di Indonesia juga berbeda-beda, teungku (Aceh), tuanku atau buya (Sumatera Barat), ajengan (Jawa Barat), kyai (Jawa Tengah dan Jawa Timur), tuan guru (Nusa Tenggara Barat). ${ }^{10}$ Di Kalimantan Selatan, ulama disebut guru, mu'allim (informal), dan tuan guru untuk sebutan formal. ${ }^{11}$

Kata ulama juga ditemukan dalam kitab suci al-Qur'an dan hadis. Dalam Q.S. al-Fathir ayat 28, disebutkan bahwa ulama adalah hamba-hamba-Nya yang takut (khasyyah) kepada kemahakuasaan-Nya, sehingga mereka mengkaji dan mengamalkan isi al-Qur'an. Dalam Q.S. al-Syu'arâ' ayat 197, Allah SWT. memperingatkan ulama Bani Israil tentang pengingkaran mereka (ke atas ajaran Islam yang disampaikan Rasulullah) karena al-Qur'an telah disebutkan

${ }^{5}$ Daudi, Maulana Syekh, 2003.

${ }^{6}$ Ahmad Rosyadi, Bertemu ke Sekumpul: Sebuah Kenangan buat Abah Guru (Martapura: t.p., 2006).

${ }^{7}$ Abdullah Karim dan Ahdi Makmur, Ulama Pendiri Pondok Pesantren di Kalimantan Selatan (Banjarmasin: PPIK-Comdes, 2006).

${ }^{8}$ Hamid Algar, "Ulama," dalam Mercia Eliada (ed.), The Encyclopedia of Religion (New York and London: Macmillan Publishing Company, 1987), Vol. 15, h. 115; Iftikhar Zaman, "Sunni Ulama," dalam John L. Esposito (ed.), The Oxford Encyclopedia of the Islamic World, Vol. IV (New York: Oxford University Press, 1995), h. 258.

${ }^{9}$ Abubakar A. Bagader (ed.), The Ulama in the Modern Muslim Nation-State (Kuala Lumpur: Muslim Youth Movement of Malaya, 1983); Ishtiaq Husain Qureshi, "The Position of the Ulama in the Muslim Society," dalam Abubaker A. Bagader (ed.) The Ulama in the Modern Muslim NationState (Kuala Lumpur: Muslim Youth Movement of Malaysia, 1983), h. 7.

${ }^{10}$ Ensiklopedia Islam (Jakarta: INIS, 1994), h. 120-121.

${ }^{11}$ Abdul Djebar Hapip, Kamus Banjar-Indonesia (Jakarta: Pusat Pembinaan dan Pengembangan Bahasa, Departemen Pendidikan dan Kabudayaan, 1977). 
dalam Kitab-Kitab yang terdahulu. ${ }^{12}$ Dalam hadis, disebutkan bahwa ulama adalah pewaris para nabi, yaitu mewarisi ilmu (agama), sifat dan perilaku para nabi, bukan kenabian atau pun harta benda. ${ }^{13}$

Keulamaaan seseorang juga mesti diakui oleh ulama lainnya dan oleh orang-orang sekitarnya, baik karena ilmunya, kesalehan, ketaatan, sikap dan prilakunya yang terpuji, ${ }^{14}$ maupun karena nasabnya. ${ }^{15}$ Karena itu, ulama adalah orang-orang yang luas ilmunya (ilmu agama), saleh, taat, berakhlak terpuji dan diakui oleh orang lain karena ilmu, prilaku atau nasabnya.

Ulama dapat dikelompokkan ke dalam beberapa kategori, yaitu ulama-i-akhirat dan 'ulama-i-duniy, ${ }^{16}$ atau ulama tradisional dan ulama intelektual, ${ }^{17}$ ulama yang mengamalkan ilmunya untuk dirinya sendiri dan orang lain, hanya untuk orang lain, dan hanya untuk dirinya sendiri, ${ }^{18}$ serta ulama tradisional dan ulama modern. ${ }^{19}$

Di negara-negara dan negeri-negeri beretnik Melayu terdapat ulama "Kaum Tua" dan ulama "Kaum Muda." ${ }^{20}$ Dari ulama "Kaum Muda" terdapat ulama revivalis dan ulama reformis atau modernis, ${ }^{21}$ ulama pemurni dan ulama pembaharu. ${ }^{22}$

Dalam perspektif kekuasaan atau politik, ada ulama birokrat (ulama pejabat) dan ulama bebas. ${ }^{23}$ Dilihat daripada tanggapan atau reaksi ulama terhadap tradisi dan perubahan dalam masyarakat, ditemukan ulama fundamentalis, tradisionalis, modernis dan pragmatis. ${ }^{24}$

\footnotetext{
${ }^{12}$ Yayasan Penyelenggara Penerjemah al-Qur'an Departemen Agama Republik Indonesia, Al-Qur'an dan Terjemahannya (Jakarta: Proyek Pengadaan Kitab Suci al-Qur'an Departemen Agama RI, 1982), h. 588, 700.

${ }^{13}$ Haderiansyah AB, "Ulama dalam Tinjauan Normatif dan Historis Keindonesian," dalam Jurnal Ilmiah Ilmu Ushuluddin, Vol. V, No. 2, (Juli-Desember, 2006), h. 102.

${ }^{14}$ Azyumardi Azra, "Ulama, Politik dan Modernisasi," dalam Ulumul Qur'an, II, No. 7 (1990), h. 5.

${ }^{15}$ Endang Turmudi, Perselingkuhan Kiai dan Kekuasaan. (Yogyakarta: LKIS, 2004) h. 9.

${ }^{16}$ Sartono Kartodirdjo, (ed.), Elit dalam Perspektif Sejarah (Jakarta: LP3ES, 1983), h. 7.

${ }^{17} Z a m a h s y a r i$ Dhofier, Tradisi Pesantren (Jakarta: LP3ES, 1985), h. 172-173.

${ }^{18} \mathrm{Ahmad}$ Fahmi Zamzam (trans.), Empat Puluh Hadits Kelebihan Ilmu dan Ulama (Derang Pokok Sena, Kedah: Khazanah Banjariah, 2004), h. 11.

${ }^{19}$ Silfia Hanani, Peranan Ulama dalam Penyebaran Islam, diakses dari www.karyanet.com.my, 2007.

${ }^{20}$ Muhamed Nawab Mohamed Osman, "Toward a History of Malaysian Ulama," paper diterbitkan oleh the Institute of Defence and Strategic Studies (IDSS), Singapore, No. 122 (February 22, 2007).

${ }^{21}$ Aminah Binti Awang Abd Rahman, "Islamic Revivalism in Eastern Malay States: The Role of Haj Abbas Muhamad in Propagiting Islam," dalam Journal of Islam in Asia, Vol. III, No. 1 (2006), h. 152.

${ }^{22}$ Harun Nasution, Pembaharuan dalam Islam: Sejarah Pemikiran dan Gerakan (Jakarta: Bulan Bintang, 1975), h. 11-26.

${ }^{23}$ S.M. Yunus Gilani, "Ilm, "Ulum and the "Ulama," dalam Hamdard Islamicus, Vol. XIII, No. 4 (2000), h. 52.

${ }^{24}$ Mir Zohair Husain, Global Islamic Politics (New York: Harper Collins College Publishers, 1995).
} 
Keempat kelompok ini kemudian lebih disederhanakan oleh Zaman ${ }^{25}$ ke dalam golongan ulama konservatif, radikal dan liberal.

Dalam konteks sosiologi, ulama dapat dikategorikan ke dalam dua tipe, yaitu ulama tradisional dan ulama modern. Kategori ini beranalog kepada tipe masyarakat dalam pandangan para tokoh ilmu sosial. Penggolongan ulama ke dalam bentuk tradisional dan modern adalah didasarkan kepada perbedaan pola budaya, struktur sosial, kelembagaan, dan sikap mereka atas perubahan sosial yang terjadi dalam masyarakat. ${ }^{26}$

Status atau kedudukan memiliki dua arti. Pertama, sekumpulan hak dan kewajiban. Kedua, tempat atau posisi seseorang dalam suatu kelompok sosial atau masyarakat. ${ }^{27}$ Karena itu, dalam status terdapat hak dan kewajiban, dan juga terdapat aspek superioriti dan inferioriti.

Status tidak bisa dipisahkan dari peranan. Pertama, peranan adalah perilaku yang diharapkan dari pemegang status. ${ }^{28} \mathrm{Kedua}$, peranan adalah serangkaian norma dan harapan yang dikenakan kepada seseorang yang memegang kedudukan. ${ }^{29}$ Ketiga, peranan adalah aspek dinamis daripada status. ${ }^{30}$ Karenanya, peranan bersifat dinamis, status bersifat statis.

Peranan juga berarti suatu proses interaksi. Dalam berinteraksi, seseorang bisa melakukan berbagai atau serangkaian peranan, ${ }^{31}$ sehingga dia (seorang yang 'alim atau ulama) dapat memainkan banyak peranan ketika berinteraksi dengan orang atau kelompok lain. Peranan ulama dalam kehidupan sosial tidak hanya terbatas dalam urusan agama atau moral. Ulama dapat berperanan sebagai tokoh religio-politik, ${ }^{32}$ pendidik,,${ }^{33}$ broker budaya, ${ }^{34}$ mediator, ${ }^{35}$

${ }^{25}$ Muhammad Qasim Zaman, The Ulama in Contemporary Islam: Custodians of Change (Princeton and Oxford: Princeton University Press, 2002), h. 5.

${ }^{26}$ Lihat gambaran masyarakat tradisional dan modern dalam John J. Macionis, Sociology (New Jersey: Pearson Prentice Hall, 2005), Tenth Edition, h. 634.

${ }^{27}$ Achmad Patoni, Peran Kiai Pesantren dalam Partai Politik (Yogyakarta: Pustaka Pelajar, 2007), h. 41-43.

${ }^{28}$ Theodore R. Sarbin, "Role," dalam David L. Sills (ed.) International Encyclopedia of Social Sciences (New York and London: The Macmillan Company \& The Free Press, 1972), Vol. 13, h. 546-552.

${ }^{29}$ Michael Banton, Roles: An Introduction to the Study of Social Relations (London: Tavistock Publication, 1965), h 29.

${ }^{30}$ Patoni, Peran Kiai, h. 45.

${ }^{31}$ Banton, Roles, h. 28; G. Duncan Mitchell, (ed.), A New Dictionary of Sociology (London: Routledge \& Kegan Paul, 1997); Warren H. Handel, Contemporary Sociological Theory (New Jersey: Prentice Hall, 1993), h. 114-115.

${ }^{32}$ Turmudi, "Religion and Politics: A Study of Political Attitudes of Devout Muslims and the Role of the Kyai in Kontemporary Java," dalam Southeast Asian Journal of Social Science, Vol. 23, No. 2 (1995), h. 18-41.

${ }^{33}$ Muhammad Redzuan Othman, "The Role of Makka Educated Malays in the Development of Early Islamic Scholarship and Education in Malaya," dalam Journal of Islamic Studies, Vol. 9, No. 2 (1998), h. 146-157.

${ }^{34}$ Geertz, "The Javanese Kijaji", h. 228-249.

${ }^{35}$ Bagader, The Ulama, 1983. 
broker politik, ${ }^{36}$ setia usaha atau administrator (keagamaan) ${ }^{37}$ termasuk sebagai penggerak modernisasi, pembangunan dan agent of change. ${ }^{38}$ Berbagai fungsi dan peranan ulama ini, bagaimanapun, dilakukan dalam upaya pembinaan masyarakat agar tetap berada dalam keseimbangan atau equilibrium.

\section{Tipologi Ulama Banjar}

Ulama yang diwakili oleh para kyai yang berkedudukan sebagai pimpinan dan atau pengajar di pondok-pondok pesantren di Kalimantan Selatan dapat dikategorikan ke dalam tradisional, tradisi-modern, dan modern. Dengan kata lain, ada ulama salafi, ada ulama salafi-khalafi dan ulama khalafi.

Secara kualitatif, data yang digunakan untuk menggambarkan tiga kategori tersebut adalah corak daripada pondok pesantren yang mereka pimpin dan profil pimpinan pondok (ulama atau kyai). Berdasarkan data Departemen Agama Kalimantan Selatan tahun 2006/ 2007, di Kalimantan Selatan terdapat 123 buah pondok bercorak salafiyah (tradisional), 86 buah khalafiyah (modern), dan 23 buah bertipe kombinasi antara corak tradisional dan modern. Begitu juga dari 40 pondok pesantren yang dikaji, 18 memiliki tipe salafiyah, 21 tipe khalafiyah, dan hanya 1 yang bertipe kombinasi.

Berdasarkan data tersebut, kyai pesantren yang bertipe khalafiyah (modern) seharusnya lebih banyak dibanding kyai pesantren yang bertipe salafiyah (tradisional). Kenyataannya tidak, karena kyai pesantren khalafiyah (modern) tidak selalu berpandangan dan berperilaku modern, begitu juga kyai pesantren salafiyah tidak semua berpandangan dan berperilaku tradisional. Beberapa kyai pesantren salafiyah dan khalafiyah memiliki pandangan dan perilaku yang lentur, sehingga tanpa disadari mereka telah membentuk kategori baru, yaitu kyai atau ulama yang bercorak tradisi-modern. Dengan demikian, terdapat kyai atau ulama yang bercorak salafi-khalafi atau tradisi-modern dalam masyarakat Banjar di Kalimantan Selatan.

Data lain adalah hasil wawancara dengan dan pengamatan terhadap tiga kyai atau ulama pimpinan pondok pesantren di tiga daerah yang berbeda. Pertama adalah pimpinan pondok pesantren (PP) Darussalam Martapura yang bercorak salafiyah-khalafiyah atau "kombinasi". Kedua adalah mantan pimpinan PP Babussalam Banjarmasin yang sekarang memimpin PP Nurut Thayyibah di Desa Tatah Pelatar Kabupaten Banjar, yang pondok pesantrennya bercorak salafiyah. Ketiga adalah pimpinan PP Nurul Muhibbin di Barabai, yang juga bercorak salafiyah. Hasilnya kemudian dirangkum ke dalam sebuah profil atau biografi singkat ketiga-tiga ulama tersebut .

Pimpinan PP Darussalam adalah salah seorang ulama yang bertipe tradisi-modern.

\footnotetext{
${ }^{36}$ Zaman, "Sunni Ulama", 1995.

${ }^{37}$ Alfani Daud, Islam dan Masyarakat Banjar (Jakarta: PT Raja Grafindo Persada, 1997), h. 55-61.

${ }^{38}$ Lihat Abdullah, Agama, 1983; lihat juga Horikoshi, Kyai, 1987.
} 
Dari perfomanya yang sederhana, menghargai orang yang berilmu, mengutamakan pengamalan keagamaan (ibadah) daripada pemahaman keagamaan (teologi), istiqamah (dalam menuntut ilmu), mempunyai hubungan dekat dengan para pejabat pemerintah, komunikatif, merespons positif terhadap ilmu-ilmu keduniaan (sekular), berwawasan luas, hingga keterlibatannya dalam aktivitas politik, mengindikasikan bahwa ia adalah seorang ulama yang masih terikat tradisi, tetapi bersikap dan berpandangan modern. Karena itu, ia termasuk ulama tradisi-modern.

Berkenaan dengan Mantan pimpinan PP Babussalam, ia adalah seorang ulama pengikut Syafi'iyah yang menghargai perilaku-perilaku modern. Ia telah memberi peluang di pondoknya untuk pembelajaran ilmu-ilmu keduniaan seperti Bahasa Indonesia, Bahasa Inggris, Ilmu Pengetahuan Alam (IPA), Ilmu Pengetahuan Sosial (IPS) dan Matematika. Namun, ia adalah seorang ulama yang sangat berpegang kokoh kepada tradisi, yaitu sangat menghormati kepada para ulama dan para wali, memimpin berbagai upacara keagamaan menurut tradisi Syafi'iyah (memimpin haulan, selamatan, dan membaca manaqib). Sebagai seorang ulama, ia tidak aktif berpolitik, kecuali mengajar dan berdakwah (memberi pengajian agama pada beberapa majlis ta'lim). Performanya juga cukup bersahaja, tinggal di rumah sederhana yang terbuat dari kayu meski ukurannya cukup besar, dan masih melakukan pekerjaan di bidang pertanian. Kedudukannya sebagai tokoh agama (kyai, ulama) yang tinggal di pinggiran kota, tidak membuat beliau meninggalkan pekerjaan yang beliau warisi secara turun temurun, yaitu sebagai seorang petani. Karena itu, ulama ini bisa dikategorikan bercorak tradisi-modern.

Sama dengan kedua kyai di atas, pimpinan PP Nurul Muhibbin adalah seorang ulama berpaham Syafi'iyah, tetapi sikap dan pandangannya cukup modern. Ini tergambar dalam sikapnya yang terbuka terhadap penerapan sistem pendidikan Islam modern, yaitu sistem berkelas dan penggunaan kurikulum madrasah serta pemberian kesempatan bagi para pelajar yang ingin memperoleh ijazah, sehingga mereka bisa melanjutkan pelajarannya ke tingkat yang lebih tinggi. Ia juga membuka program pendidikan Wajib Belajar 9 tahun yang dibina oleh Departemen Pendidikan Nasional (Wajar Diknas 9 Tahun) bagi santri dan santriwati yang tidak memiliki ijazah formal. Sikap terbuka ini menggambarkan bahwa ia juga membuka diri terhadap pemikiran modern, utamanya terhadap masalah-masalah yang berkaitan dengan peningkatan mutu pendidikan pesantren. Dengan demikian, ia bisa dikategorikan ke dalam ulama tradisi-modern.

Data yang diperoleh menyebutkan bahwa sebagian ulama Banjar bertipe tradisional (22,5\%), modern (25\%), dan tradisi-modern (52,5\%). Dengan demikian, jumlah ulama Banjar yang tradisi-modern lebih banyak dibanding ulama bertipe tradisional atau bertipe modern.

Selain itu, dilihat dari penguasaan mereka terhadap ilmu agama dan penekanan materi keagamaan yang diajarkan dalam aktivitas pendidikan (formal dan non-formal), ulama Banjar bisa juga dikategorikan sebagai ulama fikih, ulama hadis, ulama tauhid dan ulama tasawuf. Bila dilihat dari pengabdian utama mereka di masyarakat, mereka bisa digolongkan sebagai ulama pesantren dan ulama majlis ta'lim. Meski demikian, pengkategorian ini tidak rigid, sebab seorang ulama pesantren terkadang juga membuka majlis ta'lim atau mengajar 
di pengajian agama di luar pesantren. Seorang ulama majlis ta'lim juga ikut mengajar di pesantren, seorang ulama fikih juga memberikan pelajaran hadis atau tauhid di majlis ta'lim atau pesantren.

\section{Peranan Ulama dalam Membina Masyarakat Banjar}

Secara kualitatif, terdapat beberapa realitas sosial yang boleh diberi makna untuk menggambarkan peranan ulama dalam membina masyarakat Banjar di Kalimantan Selatan. Realitas sosial tersebut berhubungan dengan kepemimpinan ulama dalam berbagai upacara keagamaan (sosial keagamaan), pembimbingan dan panasehatan, kepemimpinan dalam upacara siklus kehidupan, pemberian motivasi, kepemimpinan dan keterlibatan ulama dalam aktivitas pendidikan dan dakwah, pelaku dalam pembaharuan pendidikan, dan partisipasi mereka dalam aktivitas politik.

Peranan ulama dalam memimpin berbagai upacara keagamaan (sosial keagamaan) tampak dalam posisi mereka menjadi imam salat berjama'ah, dalam memimpin aktivitas berzikir, memimpin upacara selamatan karena kelulusan (sekolah dan pegawai), promosi jabatan, keberhasilan perniagaan, dan terhindar dari musibah atau bencana, menjadi pemimpin atau pembaca doa dalam berbagai upacara (keagamaan, sosial keagamaan, kenegaraan, formal dan informal atau ibadah Umrah). Peranan lain dari ulama yang berkaitan dengan kepemimpinan dalam upacara keagamaan adalah memimpin istighasah dan upacara manakib para wali atau ulama besar, karena dianggap mempunyai karamah dan kekuatan spiritual.

Umumnya, pembacaan manakib para ulama dilaksanakan ketika memperingati kematian (haul) ulama tersebut seperti haulan Syaikh Muhammad Arsyad al-Banjari (ulama Nusantara asal Banjar abad ke-18), Tuan Guru Haji Kasyful Anwar (muassis ke-2 Pondok Pesantren Darussalam Martapura) dan al-'Alim al-'Alamah Tuan Guru Haji Muhammad Zaini Ghani (pendiri dan pimpinan Majlis Ta'lim ar-Raudhah Sekumpul Martapura); atau untuk mengenang para walî Allâh. Sebagian dari risalah atau kitab manakib yang dibaca adalah karya ulama

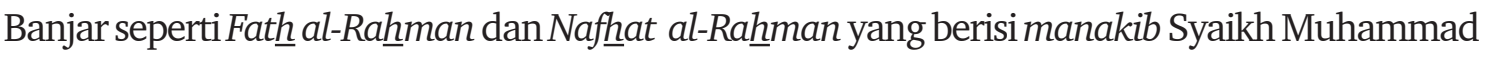
Saman al-Madani ditulis oleh Tuan Guru Haji Munawwar, pengasuh Majlis Ta'lim Mushalla Raudhatul Anwar Kampung Ilir Martapura, dan manakib Syaikh 'Abd al-Qadîr al-Jailânî fi Kitabih al-Ghunyah yang ditulis oleh Tuan Guru Haji Muhammad Syukri Unus, pengasuh Majlis Ta'lim Sabilal Anwar al-Mubarak di komplek Darussalam Martapura.

Ulama juga berperan sebagai pembimbing dan penasehat dalam aktivitas sosial keagamaan. Bimbingan dan nasehat dilakukan melalui pengajian agama, atau konsultasi di tempat tinggal ulama secara face to face. Perkara yang paling banyak dikonsultasikan adalah tentang pembagian harta warisan (farấid), perkawinan (munâkahat), hutangpiutang (mu'amalah) dan masalah 'ibâdah. Lainnya adalah masalah yang berkaitan dengan kehidupan keluarga (hubungan suami-isteri, kenakalan anak, konflik orangtua-anak, konflik mertua-menantu, termasuk perkara jodoh), masalah hidup keseharian seperti 
pekerjaan (belum mendapat pekerjaan tetap, kesiapan menerima tawaran pekerjaan, ketakseimbangan antara pendapatan dan pengeluaran), dan ketidakharmonisan hidup bertetangga.

Ada juga masyarakat yang berkonsultasi untuk pengobatan (spiritual) atau penyembuhan penyakit (fisik) atau gangguan (mental). Pimpinan PP al-Aminiyah di Banjarmasin, pimpinan PP Nurul Jannah di Banjarmasin, dan pimpinan Majlis Ta'lim Ashhaabul Maimanah di Banjarmasin adalah tiga di antara ulama yang sering dan banyak dikunjungi masyarakat. Praktik pengobatan dilakukan dengan cara memberi air yang sudah dibacakan doa (Banjar: banyu tawar). Ulama juga memberi air doa untuk keperluan lain seperti keselamatan (rumah, kendaraan atau alat transportasi, toko atau ruko, kedai atau warung), kemudahan menghadapi ujian (pelajar), atau untuk memperoleh ketenangan jiwa (Banjar: panarang hati).

Peranan lainnya para ulama dalam masyarakat Banjar ialah kepimpinan dalam upacara siklus kehidupan, yaitu dalam aktivitas sekitar kelahiran (batasmiyah, baaqiqah dan basunat), sekitar perkawinan (banikahan), dan aktivitas sekitar kematian (maniga hari, manujuh hari, manyalawi, maampatpuluh hari, manyaratus dan mahaul).

Dalam upacara batasmiyah, biasanya disediakan sedikit isi kelapa yang diparut, gula merah dan garam. Makanan ini dioleskan ke bibir atau ke lidah anak agar dia selalu berkatakata manis (dianalogkan dengan rasa gula merah yang manis), lemah lembut (dianalogkan dengan rasa parutan isi kelapa yang lemak), dan berwibawa atau selalu didengar katakatanya (dianalogkan dengan rasa garam yang asin) bila anak tersebut nantinya sudah menjadi dewasa. Setelah ulama melafalkan nama anak tersebut, yang diamini oleh para tamu atau undangan agar nama yang diberikan membawa berkah bagi anak dan kedua orangtuanya, ulama tersebut memercikkan minyak kelapa tadi ke ubun-ubun si anak yang di-tasmiyahi dan diikuti oleh keluarga dekat dan beberapa tokoh masyarakat yang hadir.

Dalam upacara 'aqîqah, penebusan seorang anak perempuan dilakukan dengan memotong seekor kambing, dan dua ekor untuk anak laki-laki. Kedua ekor kambing untuk anak laki-laki boleh dipotong sekaligus dalam upacara 'aqîqah di satu tempat, boleh juga di dua tempat. Seekor kambing disembelih di tempat tinggalnya yang baru, seekor lainnya dipotong di kampung asal kelahirannya. Kambing yang sudah disembelih atau dimasak (gulai atau kareh) disajikan bersama-sama dengan nasi putih atau nasi samin ditambah dengan nasi lemak (Banjar: nasi lamak, nasi lakatan), kue dan buah-buahan. Dalam kedua upacara religio-kultural ini, ulama berperan penting. Dia tidak hanya pemberi dan pelafal nama, atau pengokoh anak yang yang di-tasmiyahi, tetapi juga pembaca doa dan pemberi tausyiah yang berkaitan dengan kedua upacara tersebut dalam konteks ajaran Islam.

Pernikahan (Banjar: banikahan) adalah upacara yang terpenting dalam siklus kehidupan sekitar perkawinan, karena upacara ini menentukan sah-tidaknya sebuah perkawinan. Dalam upacara pernikahan, ulama berperan sebagai naib atau penghulu (Banjar: pangulu). Upacaraupacara sekitar perkawinan lainnya, seperti peminangan, penghantaran jujuran, pertunangan, dan pesta perkawinan tidak menuntut keterlibatan ulama yang lebih besar. Ulama hanya 
diminta untuk membaca doa (untuk semua upacara), dan dilibatkan sebagai tokoh masyarakat (Banjar: manuhaiakan) terutama dalam acara peminangan dan pesta perkawinan.

Sebelum akad nikah dimulai, naib atau penghulu meminta kepada orangtua (ayah kandung) atau keluarga dekat yang seketurunan darah (Banjar: asbah) untuk menyerahkan perwalian (anak, adik atau keponakan perempuan) kepada penghulu. Bila ayah kandung/ wali pengantin perempuan berhalangan (karena meninggal dunia, sakit keras, atau sedang bepergian tanpa kabar berita), maka hak perwalian diambil alih oleh seorang laki-laki dari calon pengantin perempuan yang mempunyai hubungan darah dalam keluarga inti (nuclear family). Bila semua mereka yang berhak menjadi wali tidak ada, maka perwalian diambil alih oleh penghulu sebagai wali hakim.

Setelah perwalian dilaksanakan, penghulu membacakan khutbah nikah dalam bahasa Arab. Selanjutnya, sambil menjabat tangan calon pengantin lelaki, penghulu membimbing pengucapan ijab qabul yang kemudian dijawab oleh calon mempelai lelaki tersebut. Untuk meyakinkan bahwa ijab qabul dianggap sah, penghulu minta tanggapan orang-orang yang hadir. Bila mereka mengiyakan, penghulu dengan segera mengucapkan kata "barakallah," yang berarti bahwa pernikahan sudah sah dengan diiringi harapan agar mendapat berkah dari Allah SWT. Sejak itu, calon pengantin lelaki dan perempuan dinyatakan sah menjadi pasangan suami isteri.

Selanjutnya, penghulu meminta pengantin lelaki untuk membaca sighat ta'lik sambil didengarkan oleh pengantin perempuan (isterinya) yang duduk di sampingnya. Sighat ta'lik merupakan ikrar yang mengikat suami isteri dalam sebuah kontrak perkawinan. Karena itu, pembacaan sighat ta'lik ini harus didengar, dipahami dan disepakati oleh kedua mempelai serta disaksikan oleh banyak orang.

Peranan ulama dalam masyarakat Banjar yang berhubungan dengan persekitaran kematian adalah sebagai imam salat fardhu kifayah (sembahyang jenazah), pembaca talqin di kubur dan memimpin beberapa upacara setelah seseorang meninggal dunia.

Peringatan setahun kematian dari seseorang (keluarga, guru, dan ulama) sudah menjadi tradisi dalam masyarakat Islam (Banjar). Upacara tersebut (Banjar: mahaul, bahaul) tidak hanya satu kali diperingati dan tidak selalu untuk mengingat satu orang saja (sehingga disebut haul jamak), tetapi boleh digabung dengan aktivitas keagamaan lainnya, seperti dengan peringatan maulid nabi apabila dilaksanakan di rumah, dengan pembacaan manakib dan yang paling sering adalah dengan kegiatan yasinan.

Peranan ulama dalam masyarakat Banjar juga tergambar melalui pemberian motivasi. Ulama mendorong orang untuk berbuat amar ma'rûf nahi munkar, untuk menuntut ilmu dan memberi dukungan ke atas berbagai program pembangunan daerah.

Ulamajuga berperan dalam bidang pendidikan, yang terwujud dalam bentuk kepemimpinan dan pengajaran di sekolah-sekolah agama yang disebut madrasah, pondok pesanten dan di tempat-tempat pengajian yang disebut babacaan dan majlis ta'lim. Pengajian agama 
biasanya mengambil tempat di rumah (ulama atau masyarakat), langgar atau masjid serta menggunakan kitab klasik (kitab kuning). Majlis ta'lim yang dilaksanakan di rumah ulama atau sebuah bangunan khusus, umumnya dibina dan dipimpin oleh ulama itu sendiri.

Berdakwah juga salah satu tugas utama dari ulama, baik melalui ucapan (bi al-lisân), perbuatan atau contoh tauladan (bi al-hal), maupun melalui tulisan (bi al-qalâm) dalam bentuk buku atau kitab, dan artikel di surat kabar atau majalah. Berdakwah dalam majlis ta'lim biasanya menggunakan tempat dan pengajarnya (guru, ulama) yang tetap. Sebaliknya, berdakwah di tempat-tempat yang berbeda seperti di kantor, sekolah, gedung, langgar, atau masjid dilaksanakan bersamaan dengan peringatan hari-hari besar Islam. Untuk berdakwah secara terbuka di depan publik (tabligh akbar), tidak semua ulama bisa melakukan. Berdakwah seperti di atas, termasuk tabligh akbar, memerlukan keterampilan, yaitu penguasaan keadaan (orang-orang) dan kemampuan berpidato. Berkhutbah di masjid atau menjadi khatib Jum'at adalah juga salah satu bentuk peranan ulama yang berhubungan dengan pendidikan dan dakwah.

Peranan ulama dalam pembaharuan pendidikan Islam tergambar dalam sikap positif dari sebagian mereka ke atas perubahan sistem pembelajaran yang berbentuk halaqah ke bentuk klasikal, pembukaan pondok pesantren (puteri) di lingkungan pondok pesantren (putera), pembukaan sekolah dan pemasukan bahan pelajaran umum dalam kurikulum pondok pesantren, perwujudan jaringan kerjasama dengan pihak luar, dan pengenalan alat-alat teknologi atau media pembelajaran modern di pondok pesantren.

Realitas lain yang boleh menggambarkan peranan ulama ialah keterlibatan ulama dalam aktivitas politik, walaupun masih terbatas. Beberapa ulama diketahui tidak mendukung keterlibatan ulama dalam politik, terutama masuk partai politik. Pendapat yang hampir sama juga dikemukakan oleh beberapa ulama Banjar berdasarkan hasil kajian Rahmiati dan Nor Hamidah. ${ }^{39}$ Selain kekhawatiran akan kecintaan kepada dunia, ulama yang berpolitik dapat menyebabkan perpecahan umat (Islam) karena perbedaan cara dan pandangan yang ditempuh oleh umat dan ulama. Dengan demikian, ulama memainkan peranan yang besar dalam membina masyarakat Banjar di Kalimantan Selatan. ${ }^{40}$

\section{Kedudukan Ulama dalam Masyarakat Banjar}

Secara kualitatif, kedudukan ulama dalam masyarakat Banyar sangat tinggi. Melalui pemerhatian yang dilakukan oleh pengkaji terhadap beberapa aktivitas sosial dan keagamaan, diketahui bahwa seseorang yang dianggap'âlim diperlakukan secara terhormat. Kedatangannya disambut, dihormati, dijabat tangannya bahkan dicium tangannya. Dalam banyak upacara

\footnotetext{
${ }^{39}$ Rahmiati dan Nor Hamidah, Dinamika Peran Ulama dalam Politik Praktis (Banjarmasin: Antasari Press, 2006), h. 110-130.

${ }^{40}$ Ahdi Makmur, "Peranan Ulama dalam Masyarakat Banjar di Kalimantan Selatan, Indonesia," (Disertasi, Universiti Utara Malaysia, 2010).
} 
sosial dan keagamaan, ulama disambut dan diminta duduk di depan atau di tempat khusus yang disiapkan. Dalam upacara peringatan hari-hari Besar Islam, dalam upacara perkawinan, lebih-lebih lagi dalam aktivitas pengajian agama, selamatan, pernikahan dan kematian, ulama selalu diperlakukan secara terhormat. Dalam upacara formal pun (pemerintahan atau kenegaraan), ulama diundang, dan dipersilahkan duduk di depan bersama pejabat pemerintah ketika menyambut Hari Kemerdekaan Republik Indonesia atau ulang tahun institusi-institusi pemerintahan. Menurut dua orang ulama pimpinan pondok pesantren, para pejabat selalu mengundang ulama meskipun hanya memimpin dan melaksanakan salat hajat berjamaah, atau untuk memimpin dan membaca doa.

Penghormatan dan penghargaan kepada ulama tidak saja ketika mereka masih hidup, tetapi juga setelah mereka wafat. Ada beberapa makam ulama yang masih ramai dikunjungi oleh penziarah di Kalimantan Selatan sampai masa kini, karena mereka dipercayai mempunyai karomah.

\section{Analisis terhadap Peranan Ulama dalam Membina Masyarakat Banjar di Kalimantan Selatan}

Dalam perspektif makro, ulama Banjar umumnya bercorak tradisi-modern, artinya memiliki pandangan, sikap dan perilaku yang cukup modern. Ulama juga telah memainkan peranan yang besar dan memiliki kedudukan yang tinggi dalam masyarakat Banjar. Persoalannya ialah apakah tipologi ulama yang tradisi-modern, peranan ulama yang besar dan kedudukan ulama yang tinggi boleh mengekalkan equilibrium, sehingga masyarakat Banjar di Kalimantan Selatan bersatu, harmonis, kuat kohesinya, dan mampu mengatasi berbagai tantangan internal dan eksternal.

Kata tradisional seringkali dikaitkan dengan kekolotan, keterasingan, ketinggalan zaman, sehingga terdengar agak negatif. Kata modern selalu dihubungkan dengan kekinian, kemajuan, pengikutan ke atas perkembangan zaman, mewakili pandangan, perilaku, sikap dan perfoman masa kini, sehingga menunjukan serba positif.

Semua yang tradisional tidak selamanya negatif, semua yang modern belum tentu positif. Alat ukur yang boleh dijadikan kepantasan adalah agama (utamanya dalam pandangan orang-orang Islam), dan budaya. Dengan demikian, ulama tradisional tidak harus diberi makna negatif, dan ulama modern tidak harus dianggap atau dinilai serba positif.

Sikap moderat juga wujud dalam ajaran Islam, sehingga sebagian umat Islam menolak perilaku ekstrim dan perilaku sangat toleran. Dengan sikapnya yang moderat dan cukup rasional, ulama tradisi-modern lebih banyak memberi kesempatan untuk saling berdialog sehingga boleh dibangun keakraban, persaudaraan dan solidaritas, dan sebaliknya boleh dicegah konflik dalam masyarakat. Bagaimanapun, kondisi yang baik ini akan membentuk dan menjaga kesatuan, persatuan, keharmonisan dan stabilitas dalam masyarakat, sehingga keseimbangan menjadi terkawal dan kekal. Karena masyarakatnya bersatu, harmoni dan 
stabil, kohesi individu dalam masyarakat semakin kuat, dan dengan kekuatan yang ada diharapkan setiap individu atau kelompok akan mampu menghadapi berbagai cabaran. Dengan demikian, tipologi ulama yang tradisi-modern adalah tipe ulama yang baik dan ideal.

Seorang yang 'alim atau ulama boleh memiliki banyak status, dan perkara ini juga berlaku bagi ulama Banjar. Karena banyak status, peranan mereka juga semakin banyak dalam masyarakat. Selain itu, ada norma-norma atau nilai-nilai yang dapat membuat mereka memainkan peranan yang besar. Menurut Talcott Persons sebagaimana ditulis oleh Marshall, norma-norma dan nilai-nilai yang sudah wujud dan melekat dalam status seseorang menentukan fungsi dan peranan individu dalam kelompok atau masyarakat. ${ }^{41}$ Sesuai dengan pendapat tersebut, bagaimana pun norma-norma dan nilai-nilai agama diyakini telah berpengaruh ke atas peranan ulama dalam masyarakat Banjar di Kalimantan Selatan. Dalam perspektif makro inilah, pemikiran Parsons yang turut mendasari lahirnya teori strutural-fungsionalisme dengan menonjolkan aspek norma dan nilai budaya, cukup sejalan dengan praktik atau amalan ulama Banjar ketika memainkan peranannya dalam masyarakat di Kalimantan Selatan.

Ada pula paham keagamaan yang terpola dalam kehidupan masyarakat. Karena menjadi tradisi, paham keagamaan tersebut kemudian menjadi kabur, yang timbul atau mengemuka justeru adalah aspek budayanya. Praktik pengobatan yang dilakukan oleh ulama pada hakikatnya adalah memenuhi sari'at, baik bagi ulama sendiri maupun bagi masyarakat yang datang berobat kepadanya. Paham sari'at berkait erat dengan hakekat. ${ }^{42}$

Sebagian peranan ulama menjadi alternatif, pengimbang dan pengawal dalam kehidupan masyarakat di Kalimantan Selatan. Bila peranan-peranan alternatif, pengimbang dan pengawal ini tidak dijalankan, dipastikan akan terjadi ketidakseimbangan, ketidakharmonisan, instabiliti, atau bahkan chaos dalam kehidupan masyarakat. Masyarakat datang ke tempat ulama untuk berobat dan atau meminta nasehat karena mereka tidak puas dengan bentuk pelayanan formal. Karena itu, peranan ulama dalam pengobatan dan penasehatan adalah sebuah alternatif, bahkan sebuah pilihan daripada masyarakat yang bersifat rasional. ${ }^{43}$

Pembinaan sekolah agama seperti madrasah dan pondok pesantren, pelaksanaan pengajian agama atau majlis ta'lim keduanya adalah peranan pengimbang. Karena institusi pendidikan sekular dan sekolah pemerintah lebih menekankan kemampuan intelektual daripada kemampuan spiritual dan moral, lembaga pendidikan Islam menjadi alternatif dan juga pengimbang. Di luar lembaga keluarga, hanya lembaga pendidikan agama (madrasah, pondok pesantren, pengajian agama atau majlis ta'lim) yang boleh memenuhi matlamatmatlamat keseimbangan dalam kehidupan masyarakat.

\footnotetext{
${ }^{41}$ Gordon Marshall, "Talcott Parsons," dalam A Dictionary of Sociology (Oxford: Oxford University Press, 1998), h. 1998.

${ }^{42}$ Alfani, Islam dan Masyarakat Banjar, h. 427.

${ }^{43}$ Lihat Rational Choice Theory dari Weber yang ditulis oleh James A. Bekford, "Development in the Sociology of Religion," dalam Robert G. Burgess \& Anne Murcutt (ed.) Development in Sociology (London etc.: Prentice Hall, 2001), h. 151-154.
} 
Peranan pengawal dari ulama juga boleh memenuhi matlamat-matlamat keseimbangan. Kepemimpinan ulama dalam pelbagai upacara keagamaan sepertiselamatan, tahlilan, haulan, pembacaan manakib boleh dimaknai sebagai upaya untuk menjaga dan mengekalkan tradisi Islam dan tradisi lokal. Sebagai pengawal, peranan tersebut boleh mewujudkan keseimbangan dalam masyarakat, karena kedua tradisi ini telah berakar kuat dalam kehidupan sebahagian besar masyarakat di Kalimantan Selatan. Menafikan keadaan tersebut berarti membuka konflik, sehingga wujud perilaku-perilaku negatif seperti permusuhan, pertengkaran sampai perkelahian (fisik) antar kelompok dalam masyarakat. Dengan demikian, teori struktural fungsionalisme yang digagas oleh para sosiolog terkemuka seperti Emile Durkheim (1858-1917) dan Talcott Parsons (1902-1979) masih relevan untuk memahami realitas sosial tersebut. Secara tidak langsung, peranan ulama dalam masyarakat Banjar menyokong teori struktural fungsionalisme.

Bagaimanapun, peranan ulama adalah realisasi daripada status (kedudukan) dan fungsi yang mereka miliki. Kedudukan ulama Banjar yang tinggi juga berhubungan dengan sikap mereka yang moderat (satu karakteristik dari tipe ulama tradisi-modern). Karena sikapnya moderat, banyak masyarakat menghormati dan menghargai ulama, dan perilaku mereka menjadi contoh tauladan. Begitupun, hubungan antara guru (ulama) dan murid boleh terjadi secara simbiotik atau hierarki, sehingga murid menghormati dan menghargai gurunya.

Posisi yang tinggi boleh juga dimiliki oleh seseorang atas dasar hubungan geneologis, pendidikan, kekayaan, kebolehan dan kemahiran sebagai status yang dicapai. ${ }^{44}$ Apapun asasnya, ulama selalu mendapat penghormatan dari masyarakat, dan penghormatan itu berlanjut sejak mereka masih hidup sehingga wafat. Selanjutnya, penghormatan dan penghargaan menjadi salah satu asas sehingga ulama boleh menduduki posisi tinggi dalam masyarakat. Akhirnya, posisi ulama yang tinggi boleh mengekalkan keseimbangan, membangun stabilitas, keharmonisan dan kesatuan dalam masyarakat Banjar di Kalimantan Selatan.

\section{Penutup}

Meskipun hidup di era modern, ternyata para ulama masih memainkan perananperanan tradisional yang besar dalam kehidupan masyarakat, termasuk dalam membina masyarakat Banjar di Kalimantan Selatan. Peranan tersebut tidak mungkin diabaikan karena menjadi alternatif, pengawal dan pengimbang dalam kehidupan masyarakat. Bahkan, peranan tersebut telah mendorong dan membangun terjadinya equilibrium, yaitu keseimbangan, keharmonisan dan kesatuan dalam masyarakat Banjar.

Tanpa melihat sejumlah tipologi, seperti ulama fikih, ulama tasawuf, ulama pesantren, ulama majlis ta'lim, ulama tradisional, tradisional-modern, modern, ulama melakukan peranan

${ }^{44}$ Rohana Yusof, Asas Sains Sosial dari Perspektif Sosiologi (Kuala Lumpur: Dewan Bahasa dan Pustaka, 2006), h. 113-117. 
yang besar dalam membina masyarakat Banjar di Kalimantan Selatan. Tentu saja, pengkategorian ulama ke dalam beberapa tipologi ini tidak bersifat rigid, karena ulama fikih ada yang mengabdi di pesantren dan di majlis ta'lim, juga ulama tasawuf. Begitu juga, ulama fikih, ulama tasawuf, ulama hadis, ulama pesantren dan ulama majlis ta'lim, ada yang tradisional dan ada juga yang modern, tetapi mayoritas mereka adalah bertipe tradisi-modern. Maknanya ialah bahwa mereka adalah para ulama tradisional tetapi agak terbuka terhadap pemikiran dan perilaku modern.

Selain itu, faktor-faktor demografi dan sosio-budaya tidak berkorelasi kuat dan signifikan dengan peranan ulama, kecuali faktor religiusitas. Faktor keberagamaan berkorelasi positif dengan peranan ulama. Begitupun kedudukan ulama adalah tinggi dalam masyarakat Banjar di Kalimantan Selatan karena kedalaman ilmu, kesalehan, perilakunya yang terpuji dan peranannya yang besar. Kedudukan yang tinggi dan peranan yang besar menyebabkan ulama dihargai dan dihormati, baik semasa hidupnya maupun setelah meninggal dunia. Akhirnya, para ulama juga merespons positif terhadap berbagai isu yang menyangkut perubahan sosial, modernisasi dan pembangunan di Kalimantan Selatan.

Secara teoritik, peranan ulama yang besar dalam berkehidupan sosial, beragama, berpolitik dan beraktivitas di bidang pendidikan dan dakwah berdampak ke atas keseimbangan dalam kehidupan masyarakat Banjar di Kalimantan Selatan. Interaksi sosial (antar individu atau kelompok) yang dibina oleh ulama (karena berfungsi atau berperanan) memperkuat kohesi individu atau keterikatan kelompok, sehingga mereka mampu berhadapan dengan berbagai tantangan dan perubahan sosial yang berkelanjutan. Ini bermakna bahwa teori strukturalfungsionalisme sejalan dengan realitas kehidupan ulama dalam masyarakat Banjar, sehingga menyokong terwujudnya stabilitas, keharmonisan dan integrasi masyarakat di Kalimantan Selatan.

Secara praktis, tulisan ini dapat menjadi bahan masukan bagi para pimpinan atau penentu kebijakan lembaga pendidikan yang bekal melahirkan calon-calon ulama di masa depan. Dengan mengkaji ulang kebijakan pimpinan lembaga pendidikan, mereka nantinya boleh menghasilkan para ulama yang tidak dengan kokoh mempertahankan tradisi, tetapi juga tidak menantang tradisi secara ketat. Di masa depan, masyarakat menghendaki ulama yang kokoh memegang tradisi tetapi membuka diri ke atas pandangan dan perilaku modern karena masyarakat selalu berubah dan perubahan itu tidak pernah berhenti. Ulama yang dicari sekarang ini adalah ulama yang tetap menjaga tradisi, tetapi mempunyai komitmen kepada perubahan, sehingga bisa mengekalkan equilibrium dalam masyarakat Banjar di Kalimantan Selatan.

Akhirnya, beberapa perkara yang belum dikaji secara detail dalam tulisan ini patut dipertimbangkan. Karena fokus kajian adalah peranan ulama pondok pesantren, maka ulama bukan pondok pesantren kurang mendapat pembahasan. Begitu pula penggunaan istilah tradisional (salafiyah) dan modern (khalafiyah), selain dipakai untuk mengidentifikasi tipologi ulama juga digunakan dalam sedikit pembahasan tentang corak pondok pesantren 
di Kalimantan Selatan. Kedua-dua istilah yang terakhir ini juga relevan untuk diaplikasilan dalam perbincangan lain, seperti kajian tentang gerakan ulama Kaum Tuha dan Kaum Muda di Kalimantan Selatan.

\section{Pustaka Acuan}

Abdullah, Hj. Wan Mohd. Shaghir. Wawasan Pemikiran Islam Ulama Asia Tenggara, Jilid VI. Kuala Lumpur: Persatuan Pengkajian Khazanah Klasik Nusantara \& Khazanah Fathaniyah, 2004.

Abdullah, Taufik, et al. Agama dan Perubahan Sosial. Jakarta: Rajawali, 1983.

Algar, Hamid, "Ulama," dalam Mercia Eliada (ed.) The Encyclopedia of Religion, Vol. XV. New York and London: Macmillan Publishing Company, 1987.

Ary, Donald, et al. Introduction to Research in Education. New York: Harcout Brace College Publishers, 1996.

Azra, Azyumardi. Jaringan Ulama Nusantara dengan Timur Tengah. Jakarta: Mizan, 1990.

Babbie, Earl. The Practice of Social Research, Belmont: Thomson-Wadsworth, 2004.

Bagader, Abubakar A. (ed.) The Ulama in the Modern Muslim Nation-State. Kuala Lumpur: Muslim Youth Movement of Malaya, 1983.

Banton, Michael. Roles: An Introduction to the Study of Social Relations. London: Tavistock Publication, 1965.

Beckford, James A. "Development in the Sociology of Religion," dalam Robert G. Burgess \& Anne Murcutt (ed.) Development in Sociology. London: Prentice Hall, 2001.

Borg, Walter R. and Meredith Damien Gall. Educational Research: An Introduction, Fourth Edition. New York \& London: Longman, 1983.

Cole, Stephen. The Sociological Method. Chicago: Rand McNally College Publishing Company, 1972.

Daudi, Abu. Maulana Syekh Muhammad Arsyad Al Banjari. Martapura: Yapida, 2003.

Daud, Alfani. Islam dan Masyarakat Banjar. Jakarta: RajaGrafindo Persada, 1997.

Dhofier, Zamahsyari. Tradisi Pesantren. Jakarta: LP3ES, 1985.

Ensiklopedia Islam. Jakarta: INIS, 1994.

Geertz, Clifford. "The Javanese Kijaji: The Changing Roles of a Cultural Broker," dalam Comparative Studies in Society and History, No. 2, 1960.

Gilani, S.M. Yunus. "Ilm, 'Ulum and the "Ulama," dalam Hamdard Islamicus, 13 (4), 2000, 47-62.

Grbich, Carol. Qualitative Data Analysis: An Introduction. London \& New Delhi: Sage Publications, 2007.

Haderiansyah AB. "Ulama dalam Tinjauan Normatif dan Historis Keindonesian," dalam Jurnal Ilmiah Ilmu Ushuluddin, Vol. 5 (2), Juli-Desember, 2006, 98-115. 
MIQOT Vol. XXXVI No. 1 Januari-Juni 2012

Hamka. "Peranan Ulama Sepanjang Sejarah," dalam Mimbar Ulama, No. 1, Mei 1976, 14-24.

Handel, Warren H. Contemporary Sociological Theory. New Jersey: Prentice Hall, 1993.

Hanani, Silfia. Peranan Ulama dalam Penyebaran Islam, diakses dari www.karyanet.com.my, 2007.

Hapip, Abdul Djebar. Kamus Banjar-Indonesia. Jakarta: Pusat Pembinaan dan Pengembangan Bahasa, Departemen Pendidikan dan Kabudayaan, 1977.

Horikoshi, Hiroko. Kyai dan Perubahan Sosial. Jakarta: P3M, 1987.

Hickey, Anthony A. An Introduction to Statistical Techniques for Social Research. New York: Random House, 1986.

Humaidy. "Pembaharuan Pendidikan Islam Abad XVIII di Kalimantan Selatan," dalam Masdari dan Zulfa Jamalie (ed.) Khazanah Intelektual Islam Ulama Banjar. Banjarmasin: Pusat Pengkajian Islam Kalimantan, 2003.

Husain, Mir Zohair. Global Islamic Politics. New York: Harper Collins College Publishers, 1995.

Karim, Abdullah dan Ahdi Makmur. Ulama Pendiri Pondok Pesantren di Kalimantan Selatan. Banjarmasin: PPIK-Comdes, 2006.

Kartodirdjo, Sartono (ed.). Elit dalam Perspektif Sejarah. Jakarta: LP3ES, 1983.

Konecki, Krzysztof T. "Triangulation in Dealing with the Realness of Qualitative Research," dalam Qualitative Sociological Review, 4(3), 2008.

Macionis, John J. Sociology. New Jersey: Pearson Prentice Hall, 2005.

Makmur, Ahdi. "Peranan Ulama dalam Masyarakat Banjar di Kalimantan Selatan, Indonesia." Disertasi: Universiti Utara Malaysia, Sintok Kedah, 2010.

Marshall, Gordon. "Talcott Parsons," dalam A Dictionary of Sociology. Oxford: Oxford University Press, 1998.

Miles, Matthew B. \& Michel A. Huberman. Qualitative Data Analysis: A Sourcebook of a New Method. London-New Delhi: Sage Publications, 1984.

Mitchell, G. Duncan (ed.). ANew Dictionary of Sociology. London: Routledge \& Kegan Paul, 1997.

Nasution, Harun. Pembaharuan dalam Islam: Sejarah Pemikiran dan Gerakan. Jakarta: Bulan Bintang, 1975.

Noer, Deliar. Gerakan Moderen Islam di Indonesia. Jakarta: LP3ES, 1980.

Nor, Siti Zalikhah Md. "Sumbangan dan Pengaruh Syaykh Muhammad Arsyad al-Banjary dalam Bidang Fikih di Alam Malayu," paper presented in International Seminar on the Thought of Syekh Muhammad Arsyad al-Banjari, Banjarmasin, 4-5 October 2003.

Osman, Muhamed Nawab Mohamed. "Toward a History of Malaysian Ulama," paper diterbitkan oleh the Institute of Defence and Strategic Studies (IDSS), Singapore, No. 122, February 22, 2007.

Othman, Muhammad Redzuan. "The Role of Makka Educated Malays in the Development of Early Islamic Scholarship and Education in Malaya," dalam Journal of Islamic Studies, 9(2), 1998. 
Patoni, Achmad. Peran Kiai Pesantren dalam Partai Politik. Yogyakarta: Pustaka Pelajar, 2007.

Puvenesuary, M. et al. Qualitative Research: Data Collection and Data Analysis Techniques. Sintok Kedah: Universiti Utara Malaysia, 2008.

Rahman, Aminah Binti Awang Abd. "Islamic Revivalism in Eastern Malay States: The Role of Haj Abbas Muhamad in Propagiting Islam," dalam Journal of Islam in Asia, 3(1), 2006.

Rahmiati dan Nor Hamidah. Dinamika Peran Ulama dalam Politik Praktis. Banjarmasin: Antasari Press, 2006.

Rosyadi, Ahmad. Bertemu ke Sekumpul: Sebuah Kenangan buat Abah Guru. Martapura: t.p., 2006.

Qureshi, Ishtiaq Husain. "The Position of the Ulama in the Muslim Society," in Abubaker A. Bagader (ed.) The Ulama in the Modern Muslim Nation-State. Kuala Lumpur: Muslim Youth Movement of Malaysia, 1983.

Sarwono, Jonathan. Statistik Itu Mudah. Panduan Lengkap untuk Belajar Komputasi Statistik Menggunakan SPSS 16. Yogyakarta: Penerbit Andi, 2009.

Steenbrink, Karel A. Beberapa Aspek tentang Islam di Indonesia Abad ke-19. Jakarta: Bulan Bintang, 1984.

Strauss, A. and J. Corbin. Basic of Qualitative Research: Grounded Theory, Procedures and Techniques. London: Sage Publications, 1998.

Taylor, Steven J. and Robert Bogdan. Introduction to Qualitative Research Methods: A Guidebook and Resource. New York: John Wiley \& Sons, Inc., 1998.

Turmudi, Endang. "Religion and Politics: A Study on Political Attitudes of Devout Muslims and the Role of the Kyai in Contemporary Java," dalam Southeast Asian Journal of Social Science, Singapore, Vol. 23 (2), 1995.

Turmudi, Endang. Perselingkuhan Kiai dan Kekuasaan. Yogyakarta: LKIS, 2004.

Yayasan Penyelenggara Penterjemah al-Qur'an Departemen Agama Republik Indonesia. Al-Qur'an dan Terjemahannya. Jakarta: Proyek Pengadaan Kitab Suci al-Qur'an Departemen Agama RI, 1982.

Yusof, Rohana. Asas Sains Sosial dari Perspektif Sosiologi. Kuala Lumpur: Dewan Bahasa dan Pustaka, 2006.

Zaman, Iftikhar. "Sunni Ulama," dalam John L. Esposito (ed.) The Oxford Encyclopedia of the Islamic World, Vol. IV, 1995.

Zaman, Muhammad Qasim. The Ulama in Contemporary Islam: Custodians of Change. Princeton and Oxford: Princeton University Press, 2002.

Zamzam, Ahmad Fahmi. Empat Puluh Hadits Kelebihan Ilmu dan Ulama. Kedah: Khazanah Banjariah, 2004. 